\title{
ICT Use: Educational Technology and Library and Information Science Students' Perspectives - An Exploratory Study
}

\author{
Noa Aharony \\ Bar-Ilan University, \\ Ramat Gan, Israel \\ noa.aharony@biu.ac.il
}

\author{
Miri Shonfeld \\ Kibbutzim College, \\ Tel-Aviv, Israel \\ mirish@macam.ac.il
}

\begin{abstract}
This study seeks to explore what factors influence students' ICT use and web technology competence. The objectives of this study are the following: (a) To what extent do certain elements of Rogers' (2003) Diffusion of Innovations Theory (DOI) explain students' ICT use, (b) To what extent do personality characteristics derived from the Big Five approach explain students' ICT use, and (c) To what extent does motivation explain students' ICT use. The research was conducted in Israel during the second semester of the academic year 2013-14, and included two groups of participants: a group of Educational Technology students (ET) and a group of Library and Information Science students (LIS). Findings add another dimension to the importance of Rogers' DOI theory in the fields of Educational Technology and Library and Information Science. Further, findings confirm that personality characteristics as well as motivation affect ICT use. If instructors would like to enhance students' ICT use, they should be aware of individual differences between students, and they should present to students the advantages and usefulness of ICT, thus increasing their motivation to use ICT, in the hopes that they will become innovators or early adopters.
\end{abstract}

Keywords: ICT use, Educational Technology students, Library and Information Science students, Exploratory study

\section{Introduction}

Modern economies depend on ICT (Information and Communication Technology) use and development (Hine, 2011). According to the International Telecommunications Union (2014), by the

Material published as part of this publication, either on-line or in print, is copyrighted by the Informing Science Institute. Permission to make digital or paper copy of part or all of these works for personal or classroom use is granted without fee provided that the copies are not made or distributed for profit or commercial advantage AND that copies 1) bear this notice in full and 2) give the full citation on the first page. It is permissible to abstract these works so long as credit is given. To copy in all other cases or to republish or to post on a server or to redistribute to lists requires specific permission and payment of a fee. Contact Publisher@InformingScience.org to request redistribution permission. end of 2014 there will be almost 3 billion Internet users, two thirds of them from the developing world. It seems that technologies are widely used in everyday life, as well as in workplace and academic settings. Therefore, it is very important that students be familiar with and master ICT in order to understand their learning environments, as well as their professional lives. The current research focuses on two kinds of popula-

\section{Editor: Janice Whatley}

An earlier, shorter version of this paper was presented at the Chais conference 2015, in Raanana, Israel, and included in Y. Eshet-Alkalai, I. Blau, A. Caspi, N. Geri, Y. Kalman, \& V. Silber-Varod (Eds.), Proceedings of the 10th Chais Conference for the Study of Innovation and Learning Technologies 2015: Learning in the Technological Era. Raanana: The Open University of Israel. 
tions: Educational Technology (ET) students and Library and Information Science (LIS) students. These two populations were specifically chosen, as ICT plays a major part in both their training and future work environments.

This study seeks to explore what factors influence students' ICT use and web technology competence. The research may contribute to an understanding of the variables that influence their ICT use and may lead to further inquiry in this field. The current study uses Rogers' (2003) Diffusion of Innovations Theory, as well as the Big Five model (Costa \& McCrae, 1992), and motivation theory (Deci \& Ryan, 1987) as theoretical bases from which we can predict factors that may influence students' ICT use.

The remainder of the article is organized as follows. The next section introduces the theoretical foundations and hypotheses developed for the proposed study. Research methods are provided next, followed by findings and discussion. The last section provides theoretical and practical contributions, along with a discussion of some limitations of the findings.

\section{Literature Review}

\section{Diffusion of Innovations Theory}

Rogers' (2003) Diffusion of Innovations Theory (DOI) is a widely used theoretical framework in the area of technology diffusion and adoption. The theory suggests that within a population group, innovations are not adopted at the same time by all individuals, as some people are more willing to try new ideas and technologies than others. The adoption of innovations depends on personal factors such as the following: gender, age, innovativeness, and ethnicity; social ones (e.g., education and income status); and on technological factors such as perceived usefulness and perceived benefits (Leung \& Wei, 1999). Rogers proposes that innovation, communication channels, time, and social system are the main components of DOI theory. Rogers suggests (2003) that the innovation decision process is similar to an information seeking process, where the person would like to reduce the uncertainty about the advantages and disadvantages of the innovation. This process is built of five stages: knowledge, persuasion, decision, implementation, and confirmation. In the knowledge stage the person learns about the innovation and seeks information about it. In the second stage (persuasion), the individual forms an attitude after $\mathrm{s} /$ he knows about the innovation. According to Rogers (2003), the knowledge stage is more cognitive oriented, while the persuasion stage is more affective oriented. In the third stage, the decision, the person decides whether to adopt or reject the innovation. In the fourth stage, implementation, the innovation is put into practice and in the last stage the individual looks for support for his or her decision.

Rogers (2003) suggests that the following attributes help decrease uncertainty about the innovation: (1) relative advantage, (2) compatibility, (3) complexity, (4) trialability, and (5) observability. Relative advantage is the extent to which people believe that the innovation is better than the traditional method. Compatibility refers to the extent to which people believe that the innovation is compatible with the traditional idea. Complexity addresses the extent to which people find the innovation difficult to use and understand. Trialability is the extent to which people believe that there are chances for the innovation to be experienced before deciding whether to adopt it or not, and observability addresses the extent to which results of the innovation are visible to others. The current study will focus on two-of these five attributes: relative advantage and complexity.

Rogers (2003) also presented classification categories of adopters: innovators, early adopters, early majority, late majority, and laggards. The Diffusion of Innovations Theory has been used as a theoretical framework to analyze the adoption of information technologies in both the education and library science environments. Various researchers have proposed that Rogers' theory is the 
most appropriate for exploring the adoption of technology in higher education (Borrego, Froyd, \& Hall, 2010; Medlin, 2001; Parisot, 1997). A study that was carried out in Israel examined reasons for students' poor use of Web 2.0 technology (Goldstein et al., 2012). Bowers, Ragas, \& Neely (2009) used Rogers' theory to investigate the value of Second Life as an educational tool among post-secondary instructors. Sahin (2006) suggested that Rogers' (2003) use of relative advantage, compatibility, and complexity attributes are related to the attitudes of individuals towards instructional computer use by college instructors. In addition, Tšoenyo and Wole (2012) proposed that relative advantage, complexity, and observability were the most relevant attributes to faculty attitudes towards ICT.

Addressing the library arena, Neo and Calvert (2012) found that compatibility and complexity were the most important factors to explain Facebook adoption in public libraries. Dorner and Revell (2012) used five attributes of Rogers' Diffusion of Innovations Theory as the basis for librarians' interviews while trying to explore their perceptions of promoting institutional repositories as an information resource for their clients. Rutherford (2008) classified librarians who used social software in libraries as falling into Rogers' (2003) categories of innovator and early adopter, while White (2001) examined diffusion of an innovation (Rogers, 1983) within digital reference services.

In light of the above, the first research hypotheses will be:

H1: Intensity of ICT use will be positively associated with students' perceptions of relative advantage.

H2: Intensity of ICT use will be negatively associated with students' perceptions of complexity.

\section{The Big Five}

The "Big Five" model of personality is one of the most famous measures of personality structure in recent years (Golbeck, Robles, \& Turner, 2011), and it is considered a comprehensive model that includes five major factors representing personality traits: neuroticism, extraversion, agreeableness, openness to experience, and conscientiousness (Costa \& McCrae, 1992). Various researchers have examined the model, finding validity and reliability across gender, age, and cultural lines (McCrae \& John, 1992). Each factor in the model is bipolar and contains different aspects.

According to Wang, Jackson, Zhang, and $\mathrm{Su}$ (2012), neuroticism is in contrast to emotional stability and is characterized by anxiety, sadness, irritability, moodiness, hostility, and nervous tension. Extraversion is associated with activity, energy, assertiveness, sociability, talkativeness, expressiveness, and positive emotions. Agreeableness consists of altruism, warmth, trust, modesty, cooperativeness, and tender-mindedness. Openness to experience addresses the complexity and depth of the person's mental and experiential life, and consists of curiosity, creativity, and preference for novelty. Conscientiousness refers to impulse control that contributes to task- and goaldirected behavior and is associated with discipline, reliability, responsibility, and organization.

Other research has analyzed the association between the Big Five model and technology use. Some studies explored the association between the Big Five model and technology use. In the context of Computer Based Assessment (CBA), Terzis, Moridis, and Economides (2012) propose that neuroticism has a significant negative effect on perceived usefulness and on goal expectancy. Agreeableness is related to social influence and perceived ease of use, while conscientiousness is associated with perceived ease of use. Extroversion and openness are connected with perceived importance.

Various studies examined the connection between the Big Five model and Internet use (AmichaiHamburger, 2002; Amichai-Hamburger \& Ben-Artzi, 2003; Amichai-Hamburger, Wainapel, \& 
Fox, 2002) showing that extraversion and neuroticism were significantly related to Internet use. Witt, Massman, and Jackson (2011) examined the influence of the Big Five on videogame playing, overall computer use, and communication technology use. Mark and Ganzach (2014) suggest that global Internet use is positively related to extraversion, neuroticism, and conscientiousness. Other studies focused on the relationship between the Big Five model and the use of social networks sites, showing that all five factors were related to the use of social networks sites (Ross et al., 2009; Selfhout et al., 2010; Wehrli, 2008; Zywica \& Danowski, 2008). Several studies proposed that extraversion was the most dominant factor concerning the use of social networks sites (Aharony, 2013; Gosling, Augustine, Vazire, Holtzman, \& Gaddis, 2011; Wilson, Fornasier, \& White, 2010, 2012; Zywica \& Danowski, 2008). In a recent study (Deng, Liu, Li, \& Hu, 2013), researchers found that extroversion impacts perceived satisfaction, supplementary entertainment, as well as playfulness and SNS continuance intention.

The current study will focus on three characteristics: extroversion, openness to experience, and neuroticism. Assuming that extroversion, openness to experience, and neuroticism may predict students' ICT use, the underlying assumptions of this study are:

H3: Extroversion and openness to experience will be positively associated with ICT use.

H4: Neuroticism will be negatively associated with ICT use.

\section{Motivation}

Another variable that may influence students' attitudes towards ICT is their motivation. Motivation is considered a key determinant of general behavior (Deci \& Ryan, 1987), IT acceptance behavior (Davis, Bagozzi, \& Warshaw, 1992; Moon \& Kim, 2001; Teo, Lim, \& Lai., 1999; Venkatesh \& Speier, 1999), and work-related behavior (George \& Brief, 1996; Lu, 1999). Ryan and Deci (2000) have introduced Self-Determination Theory (SDT) and suggested that when individuals' needs are satisfied, they will present optimal motivation and well-being. Alternatively, when these needs are hindered, people will have low motivation and well-being. Pritchard and Ashwood (2008) propose that "motivation is the process used to allocate energy to maximize the satisfaction of needs" (p. 6). The reasons for selecting specific behaviors are different from one individual to another, and a person's motivation is related to his/her attitudes, needs and goals.

Based on the literature review, H5 is developed:

H5: The higher the motivation students have, the greater their ICT use.

In light of the above, the objectives of this study are the following: (a) To what extent do certain elements of Rogers's (2003) Diffusion of Innovations Theory explain students' ICT use, (b) To what extent do personality characteristics derived from the Big Five approach explain students' ICT use, and (c) To what extent does motivation explain students' ICT use.

\section{Methodology}

\section{Data Collection}

The research was conducted in Israel during the second semester of the academic year 2013-14, and included two groups of participants: a group of Educational Technology students (ET) and a group of Library and Information Science students (LIS). The researchers obtained permission to investigate different graduate courses in two Israeli institutions. They gained access to two classes from the ET program at an Israeli college of education (Mobile technologies, and Social Networks) and two LIS classes at an Israeli university in the department of Library and Information Science (Information retrieval, and Introduction to Information Science). The researchers handed out 120 questionnaires to the students and explained the study's purpose. Of these 110 responses 
were received back from these groups (91.6\%), 50 responses were from college students and 60 from university students.

The sample was made up of $28(26 \%)$ men and $80(73 \%)$ women. The average age was 38 ; the youngest was 23 and the oldest was 60 . In terms of education, $57(52 \%)$ were in their first year, $38(36 \%)$ in their second year, and $12(11 \%)$ in the third year of their graduate program.

\section{Measures}

The survey covered five topics that were covered in five questionnaires: personal details, ICT use, attitudes to ICT, personality, and motivation (see Appendix). The personal details questionnaire had four parameters: age, gender, education, and institution.

The ICT use questionnaire consisted of 14 statements rated on a five-point Likert scale ( 1 =strongest disagreement; $5=$ strongest agreement). This questionnaire was previously used by the MOFET research group to measure students' ICT use in colleges of education (Shonfeld \& Goldstein, 2014). The value for the Cronbach's Alpha of this questionnaire was .82.

The attitude to ICT questionnaire was based on Rogers' Theory, and modified for this study. It was previously used by Tsoenyo and Wole (2012). It consists of nine statements rated on a fivepoint Likert scale ( $1=$ strongest disagreement; $5=$ strongest agreement). The questionnaire encompasses two factors. The first is 'relative advanced' (meaning positive attitudes towards ICT because of the advancement to the user). This section consists of items $1,2,3,5,9$. The second is complexity (meaning adverse attitudes to ICT because of difficulties using it). This section is composed of items 4, 6, 7, 8. The values of Cronbach's Alpha were .72 for both factors.

The personality questionnaire was based on the Big Five questionnaire (John, Donahue, \& Kentle, 1991) and was modified for this study. It has 24 statements rated on a five-point Likert scale $(1=$ strongest disagreement; $5=$ strongest agreement). The questionnaire includes three factors: extraversion (items 1, 4, 7, 10, 13, 16, 19, 22), neuroticism (items 2, 5, 8, 11, 14, 17, 20, 23), and openness to experience (items $3,6,9,12,15,18,21,24)$. The values of Cronbach's Alpha were $.82, .87$, and .72 respectively.

The motivation questionnaire included 6 statements rated on a 5 point Likert scale $(1=$ strongest disagreement; $5=$ strongest agreement). Cronbach's Alpha was .92. The questionnaire developed for this study is based on a section of a questionnaire used by research at MOFET institute (Shonfeld \& Goldstein, 2014). It was used for a previous study in 2007-2011 (Goldstein et al., 2012).

\section{Findings}

The aim of this study was to examine students' ICT use in the fields of Educational Technology and Library and Information Science in higher education institutions. Descriptive statistics from the questionnaire results indicate that these populations' use of ICT environments are at the level of $M($ Mean $)=3.31$ and $S D($ Standard Deviation $)=0.68$, where the mean was measured on a scale of $1-5$.

In order to examine whether there are differences between the ET students and LIS students, a one-way MANOVA was performed. The MANOVA revealed a significant difference between the two groups, $F(1.106)=18.39,. p<.0 .01 \eta^{2}=.15$. Findings reveal that ET students use ICT more often: $M=3.61, S D=.59$, than LIS students: $M=3.08, S D=.68$. A similar analysis was performed to compare men with women, but no significant difference was found. In order to examine the relationship between attitudes, personality characteristics, motivation, and the dependent variable (ICT use), researchers performed Pearson correlations, which are presented in Table1. 
ICT Use

Table 1. Pearson correlations between ICT use and research variables $(n=110)$

\begin{tabular}{|c|c|c|c|c|c|c|c|}
\hline Measures & $\begin{array}{l}\text { ICT } \\
\text { Use }\end{array}$ & $\begin{array}{l}\text { Extraver- } \\
\text { sion }\end{array}$ & $\begin{array}{l}\text { Neuroti- } \\
\text { cism }\end{array}$ & $\begin{array}{l}\text { Open- } \\
\text { ness }\end{array}$ & $\begin{array}{l}\text { Ad- } \\
\text { vanced }\end{array}$ & $\begin{array}{l}\text { Com- } \\
\text { plexity }\end{array}$ & $\begin{array}{l}\text { Motiva- } \\
\text { tion }\end{array}$ \\
\hline ICT Use & & & & & & & \\
\hline Extraversion & $\begin{array}{l}.29 * \\
*\end{array}$ & & & & & & \\
\hline Neuroticism & -.15 & $-.38 * * *$ & & & & & \\
\hline Openness & $.25^{*}$ & $.42 * * *$ & -.17 & & & & \\
\hline Advanced & $\begin{array}{l}.35^{*} \\
* *\end{array}$ & $.34 * * *$ & $-.32 * * *$ & $.30 * *$ & & & \\
\hline Complexity & $\begin{array}{l}- \\
.40 * \\
* *\end{array}$ & $-.36 * * *$ & .22 & $-.45 * * *$ & $-.58 * * *$ & & \\
\hline Motivation & $\begin{array}{l}.25^{*} \\
*\end{array}$ & .15 & $-.21 *$ & $.26 * *$ & $.32 * * *$ & $-.32 * * *$ & \\
\hline
\end{tabular}

Table 1 presents significant correlations between almost all research variables except neuroticism and the dependent variable (ICT use). Most of the correlations are positive; hence, the higher the level of extroversion, openness, motivation, and advanced, the greater the ICT use. Further, significant negative correlation was found between complexity and ICT use. In other words, the less students perceive ICT use as complex, the higher their ICT use will be.

Regarding correlations between research variables, significant positive correlations were found between extraversion and openness to experience, and advanced. Therefore, the more extroverted students are, the higher their openness to experience and their attitudes towards ICT use. Significant, negative correlations were found between extraversion and neuroticism and complexity. Therefore, the less extroverted students are, the higher their level of neuroticism and their complexity attitudes. Significant negative correlations were found between neuroticism and advanced and motivation. The more neurotic students are, the less their advanced attitude towards ICT and motivation to use ICT. Significant positive correlations were found between openness and advanced and motivation, In other words, the more open to experience students are, the higher their attitude and motivation towards ICT use. A significant negative correlation was found between openness and complexity, meaning that the less students are open to experience, the higher their level of complexity towards ICT use. A significant positive correlation was found between advanced and motivation; hence, the higher students' attitudes towards ICT use, the greater their motivation to use ICT. In addition, a significant negative correlation was found between complexity and motivation, meaning that the more students perceive ICT use as complex, the lower their motivation to use it. 
Pearson correlations were conducted between demographic variables (age and year of study) and ICT use. A significant positive correlation was found only between year of study and ICT use, $r=$ $.23, p<.05$. In other words, the higher students' year of study, the greater their ICT use.

Researchers also conducted a hierarchical regression analysis, in which the dependent variable was ICT use. The regression explained 32\% of ICT use. The predictors were entered as five steps: (1) personal details (group and education); (2) personality characteristics (openness to experience, extraversion, and neuroticism); (3) attitudes towards ICT (advanced and complexity); (4) motivation; and (5) an interaction between the research variables. In the regressions analysis, the entry of the first four steps was forced, while that of the interaction was entered according to its contribution to the explained variance. Table 2 presents the standardized and unstandardized coefficients of the hierarchical regression of respondents' ICT use.

Table 2. Hierarchical regression coefficients of respondents' ICT use $(n=110)$

\begin{tabular}{|c|c|c|c|c|c|}
\hline Step & Predictors & $\underline{B}$ & $\underline{\beta}$ & $\underline{\mathrm{R}}^{2}$ & $\underline{\Delta \mathrm{R}^{2}}$ \\
\hline \multirow[t]{2}{*}{1.} & Institution & -.50 & $-.34 * * *$ & $.17 * * *$ & $.17^{* *}$ \\
\hline & Education & .17 & $.17^{*}$ & & \\
\hline \multirow[t]{3}{*}{2.} & Extraversion & .08 & .08 & $.21 * * *$ & $.04^{*}$ \\
\hline & Neuroticism & -.03 & -.04 & & \\
\hline & Openness & .18 & $.16^{*}$ & & \\
\hline \multirow[t]{2}{*}{3.} & Advanced & .22 & $.19 *$ & $.30 * * *$ & $.09 * *$ \\
\hline & Complexity & -.18 & $-.17 *$ & & \\
\hline 4. & Motivation & .06 & .06 & $.30 * * *$ & .00 \\
\hline \multirow[t]{2}{*}{5.} & Extraversion $\mathrm{x}$ & & & & \\
\hline & Advanced & -.14 & $-.17 *$ & $.32 * * *$ & $.02 *$ \\
\hline
\end{tabular}

The first step introduced the education and group variables that contributed significantly by adding $17 \%$ to the explained variance of ICT use. The beta coefficient of the education variable is positive; hence, the higher the students' year of education, the higher their ICT use.

The second step introduced the personality characteristics (openness, extraversion, and neuroticism) of which only openness contributed significantly by adding $4 \%$ to the explained variance of ICT use. The beta coefficient of openness is positive. In other words, the more open to experience students are, the higher their ICT use.

The third step introduced the attitudes (advanced and complexity), of which only advanced contributed significantly by adding $9 \%$ to the explained variance of ICT use. The beta coefficient of advanced is positive; hence, the higher students' attitudes towards ICT, the higher their ICT use. The fourth step introduced the motivation variable, which did not contribute to the explained variance of ICT use.

As the fifth step, researchers added the interaction between Advanced X Extraversion that added $2 \%$ to the explained variance of ICT use. The interaction Advanced X Extraversion is presented in Figure 1. 


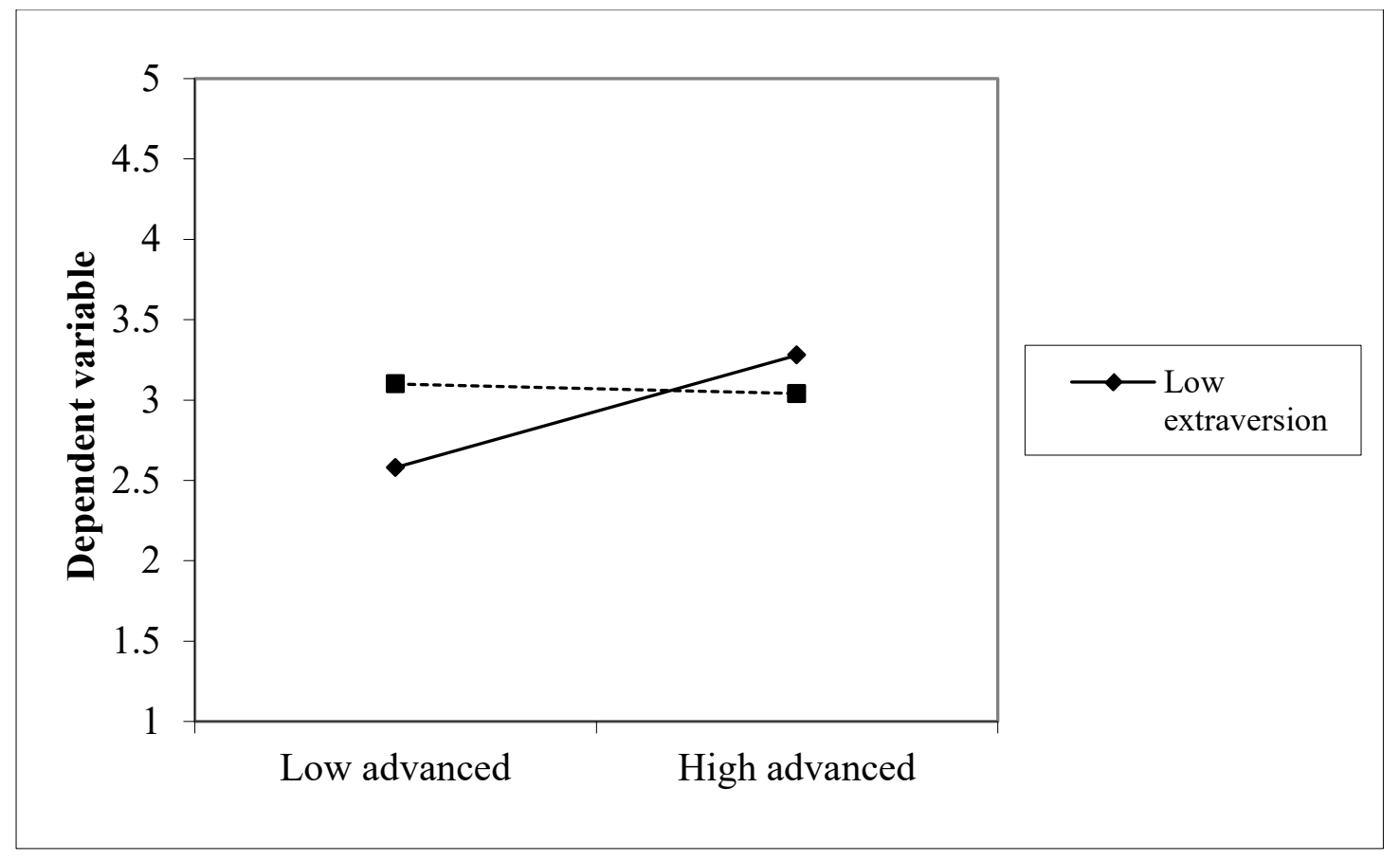

Figure 1. Interaction of advanced $X$ extraversion

A correlation was found between the extraversion and advanced variables. However, this correlation is higher among students who are less extroverted. $\beta=.34, p<0.05$, than among those who are more extroverted, $\beta=.03, p>0.05$. It seems that especially among students who are less extroverted, the more they perceive ICT use as advanced, the more they use ICT.

\section{Discussion}

Based on the premises of Rogers' Diffusion of Innovations theory, the Big Five model, and motivation theory, the present research explored the extent to which Rogers' attributes of innovations, personality characteristics, and motivation explain students' ICT use. By addressing these questions, this article makes a number of theoretical and practical contributions:

- The findings of this study add another dimension to the importance of Rogers' DOI theory in the fields of Educational Technology and Library and Information Science.

- Findings confirm that personality characteristics as well as motivation effect ICT use.

- If instructors would like to enhance students' ICT use, they should be aware of individual differences between students and handle them accordingly. Further, they should present to students the advantages and usefulness of ICT, thus increasing their motivation to use ICT, in the hopes that they will become innovators or early adopters.

Before dealing with research hypotheses, we would like to discuss the study population. Researchers assumed that because ET and LIS students deal a lot with technology, both in their learning environments and later in their professional life, participants would be classified as innovators who wish to experience new ideas and be gatekeepers in their organizations, or at least as early adopters who tend to spread the information about the innovation, decreasing others' uncertainty about it (Rogers, 2003). However, findings indicate that most students can be classified as early majority to whom the innovation decision takes more time than it takes for the innovators or the early adopters, or as late majority who will wait till most of their acquaintances adopt the innovation (Rogers, 2003). Instructors in the academic environments should be aware of this find- 
ing, and try to apply Rogers' theory in order to shift students towards the direction of innovators and early adopters. Hence, according to Rogers' theory (2003), they should begin in the knowledge stage, using cognitive reasons, to show students the importance, advantages and benefits of ICT use. In the next stage, they should try to persuade them to change their attitudes towards ICT, hoping that students will arrive at Rogers' third stage of decision, where they will use ICT more consistently becoming innovators and early adopters.

Addressing the research hypotheses, researchers divided them into three categories. The first refers to Rogers' theory $(\mathrm{H} 1, \mathrm{H} 2)$, the second $(\mathrm{H} 3, \mathrm{H} 4)$ to the Big Five Model, and the final one to motivation (H5).

Referring to the first category, it seems that both hypotheses were accepted (H1, H2). H1 showed that the more students use ICT, the higher their perceptions about its relative advantage. In other words, the more they use ICT, the more they believe it can enhance their ability and improve their efficiency. This finding echoes previous studies showing that relative advantage is associated with individuals' attitudes towards ICT use (Sahin, 2006; Tšoenyo \& Wole, 2012).

Findings addressing $\mathrm{H} 2$ show that the more students perceive ICT use as complex, difficult, or complicated, the less they use it. This finding is logical, and is in accord with earlier studies that showed ICT use is related to complexity (Neo \& Calvert, 2012; Sahin, 2006; Tšoenyo \& Wole, 2012).

Referring to Rogers' theory (2003), it was surprising to find out that ET and LIS students are not innovators or early adopters, as was supposed. However, $\mathrm{H} 1$ and $\mathrm{H} 2$ confirmed his theory about the importance of relative advantage and complexity as attributes that impact students' ICT use.

Findings concerning the second category $(\mathrm{H} 3, \mathrm{H} 4)$ reveal that only one hypothesis, H3, was accepted, showing that extroversion and openness to experience were positively correlated with ICT use. The findings indicate that the more extroverted and open to experience students are, the higher their ICT use. This finding was not unanticipated, as past studies have already shown that extroversion is strongly associated with Internet use (Amichai-Hamburger, 2002; AmichaiHamburger \& Ben-Artzi, 2003; Amichai-Hamburger et al., Wainapel, \& Fox, 2002; Mark \& Ganzach, 2014), and with social networks use (Aharony, 2013; Gosling et al., 2011; Wilson et al., 2010; Zywica \& Danowski, 2008). Considering openness to experience, Ross et al. (2009) found that heavy users of social networking sites have higher levels of openness to experience. Furthermore, Aharony (2014b) found that the more open to experience information professionals and educational technology experts were, the higher their behavioral intention to use cloud computing.

$\mathrm{H} 4$ was rejected, indicating that neuroticism was not negatively associated with ICT use. This finding stands in contrast to previous studies (Amichai-Hamburger, 2002; Amichai-Hamburger \& Ben-Artzi, 2003; Amichai-Hamburger, Wainapel, \& Fox, 2002, Mark \& Ganzach, 2014), which suggested neuroticism was significantly related to Internet use. This difference can be due to the fact that the current study focused on ICT (Information and Communication Technology) in general and not only on Internet use, as was examined previously.

$\mathrm{H} 3$ and $\mathrm{H} 4$ highlight the importance of personality differences that may affect students' ICT use. Academic instructors should be aware of these differences, understanding that not all students may adapt smoothly and naturally to technological innovations. In other words, they should make an effort to reach these populations, and try to encourage them to use ICT more constantly.

The last category, relating to motivation H5, was accepted - suggesting that the more motivation students have, the greater their ICT use. This finding strengthens the assumption that motivation is a key factor in an individual's general behavior (Deci \& Ryan, 1987), IT acceptance (Aharony, 2014a; Davis et al., 1992; Moon \& Kim, 2001; Teo et al., 1999; Venkatesh \& Speier 1999), and 
work-related behavior (George \& Brief, 1996; Lu, 1999). The current finding enhances the importance of the motivation variable, suggesting that if instructors in both academic disciplines would like to expand their students' ICT use and would like them to be innovators or early adopters, they should motivate students to use ICT, presenting the benefits, usefulness, and advantages.

Also, interesting correlations were found between the research variables. Relative advancement was positively associated with extroversion, openness to experience, and motivation. In other words, those students who perceive ICT's benefits and advantages were more extroverted, more open to experience, and more motivated to use ICT. In addition, one interaction that was performed in the study showed that, especially among students who are less extroverted, the more they perceive ICT use as advanced, the more they use it. On the other hand, complexity was negatively associated with these variables, meaning that those students who perceive ICT as complicated, were less extroverted, less open to experience and less motivated to use ICT.

\section{Conclusions}

These findings provide a more comprehensive picture, emphasizing the importance of combining elements derived from Rogers' theory and variables from the Big Five Model when trying to understand factors that may impact individuals considering adopting new technologies. In addition, these findings indicate again the fact that instructors in academic settings should be aware of individual differences, trying to make the ICT environment friendlier and less complex, thus increasing students' motivation to use ICT, and perhaps changing their predominant status from early majority and late majority to innovators and early adopters.

Further, another intriguing finding is that the higher the year of education, the higher students' ICT use. We see that these students, who have already started their studies in technology-oriented programs, use more ICT as they progress in their program. We may infer that there is an effect of the program on the intensity of their ICT use.

\section{Limitation and Future Research}

Despite its findings and implications, this study contains some limitations. First, the research was conducted on two technological programs. We may assume that results might be different with students from other departments and from other institutions. Second, the research was carried out only in Israel; therefore, it would be interesting to perform the same research in other countries. Third, in a future study, we would like to have a larger sample. Fourth, many different items have been put together on the questionnaire. In a further study we would like to concentrate on fewer items, in order to focus the research. Fifth, in order to have a comprehensive, in-depth understanding of ICT use, a future study should use also qualitative methods. 


\section{References}

Aharony, N. (2013). Factors affecting the adoption of Facebook by information professionals. Proceedings of ASIST, 50(1), 1-10.

Aharony, N. (2014a). The effect of personal and situational factors on LIS students' and professionals' intentions to use E-books. Library \& Information Science Research, 36, 106-113.

Aharony, N. (2014b). Cloud computing: Information professionals' and educational technology experts' perspectives. Library Hi Tech (In Press).

Amichai-Hamburger, Y. (2002). Internet and personality. Computers in Human Behavior, 18, 1-10. doi:10.1016/S0747-5632(01)00034-6

Amichai-Hamburger, Y., \& Ben-Artzi, E. (2003). Loneliness and internet use. Computers in Human Behavior, 19, 71-80.

Amichai-Hamburger, Y., Wainapel, G., \& Fox, S. (2002). On the internet no one knows I'm an introvert: Extroversion, neuroticism, and internet interaction. Cyber Psychology \& Behavior, 5(2), 125-128.

Borrego, M., Froyd, J. E., \& Hall, T. S. (2010). Diffusion of engineering education innovations: A survey of awareness and adoption rates in U.S. engineering departments. Journal of Engineering Education, 99, 185-207.

Bowers, K. W., Ragas, M. W., \& Neely, J. C. (2009). Assessing the value of virtual worlds for postsecondary educators: A survey of innovators, early adopters and the early majority in Second Life. International Journal of Humanities and Social Sciences, 3(1), 40-50.

Costa, P. T., \& McCrae, R. R. (1992). Revised NEO personality inventory: NEO PI-R and NEO FiveFactor inventory. NEO-FFI Professional Manual. Odessa, FL: Psychological Assessment Resources.

Davis, F. D., Bagozzi, R. P., \& Warshaw, P. R. (1992). Extrinsic and intrinsic motivation to use computers in the workplace. Journal of Applied Social Psychology 22(14), 1111-1132.

Deci, E. L., \& Ryan, R. M. (1987). The support of autonomy and the control of behavior. Journal of Personality and Social Psychology, 53(6), 1024-1037.

Deng, S., Liu, Y., Li, H., \& Hu, F. (2013). How does personality matter? An investigation of the impact of extraversion on individuals' SNS use. Cybersychology, Behavior, and Social Networking, 16(8), 575581.

Dorner, D. G., \& Revell, J. (2012). Subject librarians' perceptions of institutional repositories as an information resource. Online Information Review, 36(2), 261- 277.

George, J. M., \& Brief, A. P. (1996). Motivational agendas in the workplace: The effects of feelings on focus of attention and work motivation. Research in Organizational Behavior, 18, 75-109.

Golbeck, J., Robles, C., \& Turner, K. (2011). Predicting personality with social media. Proceedings of the 2011 annual conference: Extended abstracts on human factors in computing systems. CHI EA '11, 253-262.

Goldstein, O., Waldman, N., Tesler, B., Shonfeld, M., Forkosh-Baruch, A. Zelkovitz...Zidan, W. (2012). Preparing student teachers for computer-aided teaching and the integration of information and communication technologies in colleges of education: The state in the 2008-2009 academic year. Dapim, 54, $20-67$.

Gosling, S., Augustine, A. A., Vazire, S., Holtzman, N., \& Gaddis, S. (2011). Manifestations of personality in online social networks: Self-reported Facebook-related behaviors and observable profile information. Cyberpsychology, Behavior, and Social Networking, 14, 483-488.

Hine, P. (Ed.). (2011). ICT competency framework for teachers. Paris, France: United Nations Educational, Scientific and Cultural Organization. Retrieved from http://unesdoc.unesco.org/images/0021/002134/213 


\section{ICT Use}

International Telecommunications Union. (2014). The world in 2014: ICT facts and figures. Retrieved from http://www.itu.int/en/ITU-D/Statistics/Documents/facts/ICTFactsFigures2014-e.pdf

John, O. P., Donahue, E. M., \& Kentle, R. L. (1991). The Big Five inventory-Versions 4a and 54. Berkeley, CA: University of California, Institute of Personality and Social Research.

Leung, L., \& Wei, R.A.N. (1999). Who are the mobile phone have-nots? Influences and consequences. New Media and Society, 1(2), 209-226.

Lu, L. (1999). Work motivation, job stress and employees' well-being. Journal of Applied Management Studies, 8(1), 61-72.

Mark, G., \& Ganzach, Y. (2014). Personality and internet usage: A large-scale representative study of young adults. Computers in Human Behavior Computers in Human Behavior, 36, 274-281.

McCrae, R., \& John, O. (1992). An introduction to the Five-Factor Model and its applications. Retrieved from http://psych.colorado.edu/ carey/Courses/PSYC5112/Readings/psnBig5_Mccrae03.pdf

Medlin, B. D. (2001). The factors that may influence a faculty member's decision to adopt electronic technologies in instruction (Doctoral dissertation, Virginia Polytechnic Institute and State University). ProQuest Digital Dissertations. (UMI No. AAT 3095210)

Moon, J. W., \& Kim, Y. G. (2001). Extending the TAM for a World-Wide-Web context. Information and Management, 38(4), 217-230.

Neo, E., \& Calvert, P. (2012). Facebook and the diffusion of innovation in New Zealand public libraries. Journal of Librarianship and Information Science, 44(4), 227-237.

Parisot, A. H. (1997). Distance education as a catalyst for changing teaching in the community college: Implications for institutional policy. New Directions for Community Colleges, 99, 5-13.

Pritchard, R. D. \& Ashwood, E. L. (2008). Managing motivation. A manager's guide to diagnosing and improving motivation. New York, NY: Routledge.

Rogers, E. M. (1983). Diffusion of innovations (3rd ed.). New York, NY: Free Press.

Rogers, E. M. (2003). Diffusion of innovations (5th ed.). New York, NY: Free Press.

Ross, C., Orr, E. S., Sisic, M., Arseneault, J. M., Simmering, M. G., \& Orr, R. R. (2009). Personality and motivations associated with Facebook use. Computers in Human Behavior, 25, 578-586.

Rutherford, L. (2008). Implementing social software in public libraries: An exploration of the issue confronting public library adopters of social software. Library Hi Tech, 26(2), 184-200.

Ryan, R. M., \& Deci, E. L. (2000). Self-determination theory and the facilitation of intrinsic motivation, social development, and well-being. American Psychologist, 55(1), 68-78.

Sahin, I. (2006). Detailed review of Rogers' Diffusion of Innovations theory and educational technologyrelated studies based on Rogers' theory. Turkish Online Journal of Educational Technology, 5(2), article 3.

Selfhout, S., Burk, W., Branje, S., Denissen, J., vanAken, M., \& Meeus, M. (2010). Emerging late adolescent friendship networks and Big Five personality traits: A social network approach. Journal of Personality, 78(2), 509-538.

Shonfeld, M., \& Goldstein, O. (2014). ICT integration in teaching and teachers training by faculty members in Israeli colleges of education. In M. Searson \& M. Ochoa (Eds.), Proceedings of Society for Information Technology \& Teacher Education International Conference 2014 (pp. 403-409). Chesapeake, VA: AACE.

Teo, T. S. H., Lim, V. K. G., \& Lai, R. Y. C. (1999). Intrinsic and extrinsic motivation in Internet usage. OMEGA International Journal of Management Science, 27(1), 25-37. 
Terzis, V., Moridis, C. N., \& Economides, A. A. (2012). How student's personality traits affect Computer Based Assessment acceptance: Integrating BFI with CBAAM. Computers in Human Behavior, 28 (5), 1985-1996.

Tšoenyo, J., \& Wole, O. (2012). Analyzing the influence of Diffusion of Innovation attributes on lecturers' attitudes toward information and communication technologies. Human Technology, 8(2), 179-197.

Venkatesh, V., \& Speier, C. (1999). Computer technology training in the workplace: A longitudinal investigation of the effect of mood. Organizational Behavior and Human Decision Processes, 79(1), 1-28.

Wang, J., Jackson, L., Zhang, D., \& Su, Z. (2012). The relationships among the Big Five Personality factors, self-esteem, narcissism, and sensation-seeking to Chinese University students' uses of social networking sites (SNSs). Computers in Human Behavior, 28, 2313-2319.

Wehrli, S. (2008, September). Personality on social network sites: An application of the Five Factor model (ETH Zurich Sociology Working Paper No. 7). Retrieved from: http://repec.ethz.ch/ets/papers/wehrli_studivz_big5.pdf

White, M. D. (2001). Diffusion of an innovation: Digital reference service in Carnegie Foundation Master's (Comprehensive) Academic Institution Libraries. Journal of Academic Librarianship, 27(3), 173-187.

Wilson, K., Fornasier, S., \& White, K. M. (2010). Psychological predictors of young adults' use of social networking sites. Cyberpsychology, Behavior, and Social Networks, 13(2), 173-177

Witt, E., Massman, A., \& Jackson, L. (2011). Trends in youth's videogame playing, overall computer use, and communication technology use: The impact of self-esteem and the Big Five personality factors. Computers in Human Behavior, 27, 763-769.

Zywica, J., \& Danowski, J. (2008). The faces of Facebookers: Investigating social enhancement and social compensation hypotheses. Journal of Computer-Mediated Communication, 14(1), 1-34. 


\section{Appendix}

\section{Personal Details}

1. Male / Female

2. Age

3. Education: M.A. degree: $1^{\text {st }}$ year, $2^{\text {nd }}$ year, $3^{\text {rd }}$ year

\section{ICT Questionnaire}

Please read the following statements and mark with $\mathrm{X}$ the column which describes your accordance with the following statements ( $1=$ strongly disagree; $5=$ strongly agree).

\begin{tabular}{|c|c|c|c|c|c|}
\hline I use these platforms for my professional and personal needs & 1 & 2 & 3 & 4 & 5 \\
\hline \multicolumn{6}{|l|}{ 1. Word processing } \\
\hline \multicolumn{6}{|l|}{ 2. Presentations (such as Power Point) } \\
\hline \multicolumn{6}{|l|}{ 3. Electronic spreadsheet } \\
\hline \multicolumn{6}{|l|}{ 4. Collaborative platforms such as Google Docs } \\
\hline \multicolumn{6}{|l|}{ 5. Social networks sites } \\
\hline \multicolumn{6}{|l|}{ 6. Smart phones or tablets applications } \\
\hline \multicolumn{6}{|l|}{ 7. Wikis } \\
\hline \multicolumn{6}{|l|}{ 8. Blogs } \\
\hline \multicolumn{6}{|l|}{ 9. Communication systems based on the Internet (such as Skype) } \\
\hline \multicolumn{6}{|l|}{ 10. Media sites (such as YouTube) } \\
\hline \multicolumn{6}{|l|}{ 11. Simulations, software, electronic games } \\
\hline \multicolumn{6}{|l|}{ 12. An a-synchronic teaching and learning system } \\
\hline \multicolumn{6}{|l|}{ 13. Learning management system (such as Moodle) } \\
\hline 14. MOOCs & & & & & \\
\hline
\end{tabular}

\section{Attitude Questionnaire}

Please read the following statements and circle the number that best describes your attitudes towards ICT. Please mark with $\mathrm{X}$ the column which describes your accordance with the following statements $(1=$ strongly disagree; $5=$ strongly agree $)$.

\begin{tabular}{|l|l|l|l|l|l|}
\hline When you think of ICT... & 1 & 2 & 3 & 4 & 5 \\
\hline 1. It can improve my efficiency when I use it. & & & & & \\
\hline $\begin{array}{l}\text { 2. Mistakes with ICT transactions are easier to correct than manual } \\
\text { ones. }\end{array}$ & & & & \\
\hline
\end{tabular}




\begin{tabular}{|l|l|l|l|l|}
\hline 3. There are enough advantages of ICT for me to consider using them. & & & & \\
\hline $\begin{array}{l}\text { 4. Mistakes are more likely to occur with ICT usage than with manual } \\
\text { operations. }\end{array}$ & & & & \\
\hline 5. ICTs help me to better manage my time. & & & & \\
\hline 6. ICTs are complicated to learn. & & & & \\
\hline 7. ICTs are difficult to understand and use. & & & & \\
\hline 8. ICTs are confusing & & & & \\
\hline 9. It is easy to use ICTs even if one has not used them before & & \\
\hline
\end{tabular}

\section{The Big Five Questionnaire}

Here are a number of characteristics that may or may not apply to you. For example, do you agree that you are someone who likes to spend time with others? Please write a number next to each statement to indicate the extent to which you agree or disagree with that statement $(1=$ strongly disagree; 5 = strongly agree).

\begin{tabular}{|l|l|l|l|l|l|}
\hline $\begin{array}{l}\text { I see Myself as } \\
\text { Someone Who.. }\end{array}$ & $\begin{array}{c}\text { 1. Disagree } \\
\text { strongly }\end{array}$ & $\begin{array}{c}\text { 2. Disagree } \\
\text { a little }\end{array}$ & $\begin{array}{c}\text { 3. Neither } \\
\text { agree nor } \\
\text { disagree }\end{array}$ & $\begin{array}{c}\text { 4. Agree } \\
\text { a little }\end{array}$ & $\begin{array}{c}\text { 5. Agree } \\
\text { strongly }\end{array}$ \\
\hline 1.Is talkative & & & & & \\
\hline 2.Is depressed, blue & & & & & \\
\hline $\begin{array}{l}\text { 3.Is original, comes } \\
\text { up with new ideas }\end{array}$ & & & & & \\
\hline 4. Is reserved & & & & & \\
\hline $\begin{array}{l}\text { 5.Is relaxed, han- } \\
\text { dles stress well }\end{array}$ & & & & & \\
\hline $\begin{array}{l}\text { 6.Is curious about } \\
\text { many different } \\
\text { things }\end{array}$ & & & & & \\
\hline 7.Is full of energy & & & & & \\
\hline 8.Can be tense & & & & & \\
\hline $\begin{array}{l}\text { 9.Is ingenious, a } \\
\text { deep thinker }\end{array}$ & & & & & \\
\hline $\begin{array}{l}\text { 10.Generates a lot } \\
\text { of enthusiasm }\end{array}$ & & & & & \\
\hline 11.Worries a lot & & & & & \\
\hline $\begin{array}{l}\text { 12.Has an active } \\
\text { imagination }\end{array}$ & & & & & \\
\hline
\end{tabular}


ICT Use

\begin{tabular}{|l|l|l|l|l|l|}
\hline $\begin{array}{l}\text { 13.Tends to be qui- } \\
\text { et }\end{array}$ & & & & & \\
\hline $\begin{array}{l}\text { 14.Is emotionally } \\
\text { stable, not easily } \\
\text { upset }\end{array}$ & & & & & \\
\hline 15.Is inventive & & & & \\
\hline $\begin{array}{l}\text { 16.Has an assertive } \\
\text { personality }\end{array}$ & & & & & \\
\hline 17.Can be moody & & & & & \\
\hline $\begin{array}{l}\text { 18.Values artistic, } \\
\text { aesthetic experi- } \\
\text { ences }\end{array}$ & & & & & \\
\hline $\begin{array}{l}\text { 19.Is sometimes } \\
\text { shy, inhibited }\end{array}$ & & & & & \\
\hline $\begin{array}{l}\text { 20.Prefers work } \\
\text { that is routine }\end{array}$ & & & & & \\
\hline $\begin{array}{l}\text { 21.Is outgoing, so- } \\
\text { ciable }\end{array}$ & & & & & \\
\hline $\begin{array}{l}\text { 22.Likes to reflect, } \\
\text { play with ideas }\end{array}$ & & & & & \\
\hline $\begin{array}{l}\text { 23.Has few artistic } \\
\text { interests }\end{array}$ & & & & & \\
\hline $\begin{array}{l}\text { 24.Is sophisticated } \\
\text { literature music, or }\end{array}$ & & & & & \\
\hline
\end{tabular}

\section{Motivation Questionnaire}

Please read the following statements and circle the number that best describes your attitudes towards ICT adoption. Please mark with X the column which describes your accordance with the following statements $(1=$ strongly disagree; $5=$ strongly agree $)$.

\begin{tabular}{|c|c|c|c|c|c|}
\hline & 1 & 2 & 3 & 4 & 5 \\
\hline 1. I am interested to study subjects that are related to ICT. & & & & & \\
\hline 2. I am ready to devote a lot of time and practice, in order to master ICT. & & & & & \\
\hline 3. The subject of ICT interests me very much. & & & & & \\
\hline 4. I am ready to make many efforts to master ICT. & & & & & \\
\hline 5. Understanding ICT is very important for me. & & & & & \\
\hline 6. I would like to succeed and understand ICT. & & & & & \\
\hline
\end{tabular}




\section{Biographies}

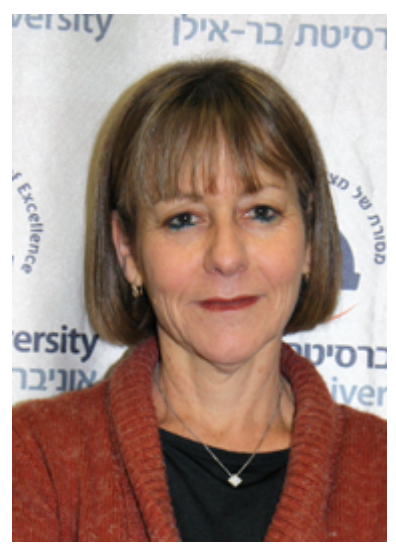

Prof. Noa Aharony received her Ph.D. in 2003 from the School of Education at Bar-Ilan University (Israel). She is the head of the Information Science Department at Bar-Ilan University (Israel). Her research interests are in education for library and information science, information literacy, technological innovations and the LIS community, and Web 2.0. Prof. Aharony is a member of the editorial boards of Journal of Librarianship and Information Science, and Online Information Review. Prof. Aharony has published in refereed LIS and education journals.

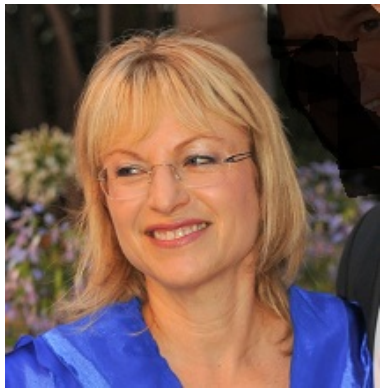

Dr. Miri Shonfeld is head of the TEC Center at MOFET Institute. She was the head of ICT and the coordinator of the graduate program of Technology in Education at Kibbutzim College of Education, Technology and the Arts. She specializes in the fields of ICT, collaborative learning, multicultural education, not only in research but in organizing activities as well, in Israel and in international organizations. She received her Ph.D. in computer science from NSU, Florida, USA. 